\section{Inducing Sterility in Carolina Laurel Cherry Using Gamma Irradiation}

\author{
John M. Ruter ${ }^{1}$
}

Additional index words. andromonoecy, Cobalt-60, flowering, germination, Prunus caroliniana, seed

Summary. Carolina laurel cherry (Prunus caroliniana) is native to the U.S. southeastern coastal plain from North Carolina westward to eastern Texas. The species has been planted extensively in the southeast as an ornamental tree or hedge. Unfortunately, carolina laurel cherry naturalizes readily and is now found in a variety of habitats, both natural and disturbed. Flowering occurs in the late winter/early spring before new leaves emerge and fruit ripens in the fall/winter. Fruit is eaten by migratory birds and seed is dispersed. Seedlings readily germinate in the understory of forests and landscapes in the spring. As there are a limited number of cultivars available, selections with improved form and sterility are needed for the landscape trade. In 2008, seed was collected and treated with Cobalt- 60 gamma irradiation at rates ranging from 0 to $150 \mathrm{~Gy}$. The lethal dose killing $50 \%$ of the seedlings $\left(\mathrm{LD}_{50}\right)$ was between 50 and $100 \mathrm{~Gy}$. Three sterile plants were selected in 2012 from the M1 (first generation of mutagen-treated seedlings) population totaling 62 seedlings. M2 (second-generation seedlings from M1 parents) seed was collected Fall 2012, and 1509 seedlings were grown to flowering size in containers. In 2014-15, 120 seedlings that showed no fruit production were planted in the field in Watkinsville, GA, for further evaluation. Ratings on field-grown plants in Dec. 2017 and 2018 showed that $73 \%$ and $78 \%$ of the plants, respectively, produced no fruit, whereas the remaining plants had minimal to heavy fruit set. Because carolina laurel cherry is andromonoecious, production of male and bisexual flowers was evaluated on 17 selections in 2018. Of 500 flowers evaluated per selection, the number of male flowers per plant ranged from 22 to $415(4.4 \%$ to $83 \%)$. The number of racemes with all-male flowers on each selection ranged from 1 to 32 . There were no significant correlations between the number of male flowers or number of all-male flowered racemes per plant and production of fruit. Approximately 5\% of M2 seedlings remain seedless after 6 years of growth.

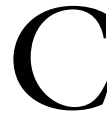
arolina laurel cherry is native to the coastal plain region of the southeastern United States from coastal North Carolina to eastern Texas [U.S. Department of Agriculture (USDA), 2018]. As a plant in the landscape, this species is often used for hedges or as a small

Received for publication 31 Jan. 2019. Accepted for publication 15 Mar. 2019

Published online 7 August 2019

${ }^{1}$ University of Georgia, Department of Horticulture, 327 Hoke Smith, Athens, GA 30602

The assistance of Betty Schroeder, Vickie Waters, Kaitlin Barrios, Yongjun Yue, and the staff at the Center for Applied Nursery Research in Dearing, GA, is appreciated. I thank Dr. Wayne Hanna for the irradiation of seed used in this study.

This paper was part of the Invasive Plants Research Professional Interest Group workshops "Strategies for Mitigating Invasiveness of Native Species," held on 30 Sept. 2017 in Waikoloa, HI, and "It's Native. Wait! It's Exotic... Oh No, It's a Nuisance!" held on 3 Aug. 2018 in Washington, DC.

J.M.R. is the corresponding author. E-mail: ruter@ uga.edu.

This is an open access article distributed under the CC BY-NC-ND license (https://creativecommons.org/ licenses/by-nc-nd/4.0/).

https://doi.org/10.21273/HORTTECH04289-19 tree. In Georgia, the original range of the plant has been questioned because the plant naturalizes freely (Godfrey, 1988). Michaux (1819) indicated that the species was mostly confined to the islands of the coasts of the Carolinas, Georgia, and Florida and was rarely found on the mainland more than a few miles from the coast. Harper (1906) noted the species from only a few locations in south Georgia, being "so rare that its indigeneity might be questioned." Duncan (1950) mentions that the plant grows naturally along the east coast and in southwestern Georgia. Several authors noted that this species is commonly found as an escape from cultivated plants (Duncan, 1950; Godfrey, 1988; Harper, 1906; Radford et al., 1968).

In the southeast United States, carolina laurel cherry flowers from February to April and the fruit ripens in the fall/winter. In northern Florida, the fruit is a primary food source for the american robin (Turdus migratorius) and the cedar waxwing (Bombycilla cedorum) (Skeate, 1987). As these bird species migrate north in late winter, they eat the fruit while perched in large deciduous trees and produce purplishblack fecal deposits, which are a nuisance in the landscape and on cars. In Athens, GA, american robins are often present in late February to early March (J.M. Ruter, personal observation). Numerous seedlings can be found germinating under trees of the species or in urban areas (Dirr, 1998; Gilman and Watson, 2006). Godfrey (1988) indicates that this species can be found in uplands, wooded slopes, near rivers, in maritime hammocks, along fencerows, and in vacant lots. In southern Georgia, the species will readily reseed and grow in the understory of abandoned pecan (Carya illinoinensis) orchards (J.M. Ruter, personal observation). The species is considered to be a facultative upland plant (USDA, 2018) and research has shown that the species is not tolerant of flooding (Ranney, 1994).

Although carolina laurel cherry is an attractive landscape plant with glossy foliage and good drought tolerance once established, only a few ornamental cultivars are available in the trade. Compact growth and reduced fruit set would be good attributes for future selections. Mutation breeding using gamma irradiation has been used to develop a number of ornamental cultivars (Shu et al., 2012). Traits that can be influenced by mutation breeding include time of flowering and fruit ripening, pollen

\begin{tabular}{llll}
\hline $\begin{array}{l}\text { Units } \\
\text { To convert U.S. to SI, } \\
\text { multiply by }\end{array}$ & U.S. unit & SI unit & $\begin{array}{l}\text { To convert SI to U.S., } \\
\text { multiply by }\end{array}$ \\
\hline 0.3048 & $\mathrm{ft}$ & $\mathrm{m}$ & 3.2808 \\
3.7854 & gal & $\mathrm{L}$ & 0.2642 \\
2.54 & inch $(\mathrm{es})$ & $\mathrm{cm}$ & 0.3937 \\
48.8243 & $\mathrm{lb} / 1000 \mathrm{ft}^{2}$ & $\mathrm{~kg} \cdot \mathrm{ha}^{-1}$ & 0.0205 \\
0.5933 & $\mathrm{lb} / \mathrm{yard}{ }^{3}$ & $\mathrm{~kg} \cdot \mathrm{m}^{-3}$ & 1.6856 \\
28.3495 & $\mathrm{oz}$ & $\mathrm{g}$ & 0.0353 \\
7.4892 & $\mathrm{oz} / \mathrm{gal}$ & $\mathrm{g} \cdot \mathrm{L}^{-1}$ & 0.1335 \\
$\left({ }^{\circ} \mathrm{F}-32\right) \div 1.8$ & ${ }^{\circ} \mathrm{F}$ & ${ }^{\circ} \mathrm{C}$ & $\left({ }^{\circ} \mathrm{C} \times 1.8\right)+32$ \\
& & &
\end{tabular}


abortion and sterility, improved disease and pest resistance, changes in environmental adaptability, and variations in growth habit. Advantages of using Cobalt-60 gamma irradiation include few disposal problems, high reproducibility, good penetration in plant tissue, and the rate of mutation frequency is high (Shu et al., 2012). The purpose of this research was to develop attractive selections of carolina laurel cherry that are sterile or have reduced fruit set that can be grown and used in the landscape.

\section{Materials and methods}

Seed from two trees of carolina laurel cherry growing on the University of Georgia Tifton Campus were collected and cleaned during Winter 2008. After cleaning, the seed was cold-moist stratified for $30 \mathrm{~d}$ at $38^{\circ} \mathrm{F}$ before treatment. The seed was sorted into batches of 50 seeds, kept separate by parental tree, and irradiated at 50 , 100, and 150 Gy using a Cobalt-60 gamma irradiation source on the Tifton Campus. The nonirradiated seed was planted as a control. Batches of seed were sown 50 per container and germinated in a glass greenhouse with set points of $75 / 65^{\circ} \mathrm{F}$ day/night temperatures. A total of 200 seeds per parental tree (four treatments $\times$ 50 seeds per treatment) were sown. Seed germination treatments were ended after $60 \mathrm{~d}$. Seedlings were potted into individual 2.25 -inch containers using a soilless substrate for further evaluation. In 2009, surviving seedlings were potted into \#l $(2.8-\mathrm{L})$ containers using a $90 \%$ pine bark: $10 \%$ sand substrate amended with dolomitic limestone, micronutrients, and $15 \mathrm{~N}-4 \mathrm{P}-10 \mathrm{~K}$ controlled-release fertilizer (Osmocote; ICL Specialty Fertilizers, Dublin, $\mathrm{OH}$ ) applied to the top of the substrate at the rate of $15 \mathrm{~g}$ per container. Plants were grown outside on black ground cloth and received overhead sprinkler irrigation at the rate of 0.4 inch per application as needed.

In 2010, 62 remaining seedlings from the irradiation treatments $(\mathrm{Ml})$ were transferred to the Center for Applied Nursery Research in Dearing, GA. On 2 June 2010, the plants were transplanted into \#7 (19.6-L) containers using a $100 \%$ pine bark substrate amended with dolomitic limestone, gypsum, micronutrients, and $18 \mathrm{~N}-$ 2.6P-10K controlled-release fertilizer
(Osmocote Pro; ICL Specialty Fertilizers) at the rate of $12.5 \mathrm{lb} / \mathrm{yard}^{3}$. Plants were grown outside on a gravel container pad and received overhead irrigation from sprinklers as needed at the rate of 0.5 to 1.0 inch per application depending on container volume and size of the plant canopy. the population of $62 \mathrm{Ml}$ seedlings were collected in Fall 2012, cleaned, stratified, and germinated. On 12 Apr. 2013, 1509 M2 seedlings in 2.25-inch pots were shifted into \#3 $(8.4 \mathrm{~L})$ containers for further evaluation and were produced as previously described. Plants held for more than one growing season had $18 \mathrm{~N}-2.6 \mathrm{P}-$ $10 \mathrm{~K}$ controlled-release fertilizer applied to the top of the substrate each spring at the rate of $19 \mathrm{~g} \cdot \mathrm{L}^{-1}$ container volume.

In May 2014, three Ml seedlings and $18 \mathrm{M} 2$ seedlings were selected for not setting seed. In Dec. 2015,102 seedlings were selected for apparent sterility. As seedlings were selected, they were transferred to the Durham Horticulture Farm in Watkinsville, GA, and were planted in the field (Cecil sandy clay loam, Typic Hapludult, Ultisol). Plants were spaced $10 \mathrm{ft}$ within rows, 12.5 $\mathrm{ft}$ between rows, irrigated as needed with drip irrigation, and fertilized
Open-pollinated seed (M2) from

annually in April with a broadcast application of $10 \mathrm{~N}-4.4 \mathrm{P}-8.3 \mathrm{~K}$ granular fertilizer (Tri County Fertilizer and Specialty Co., Honea Path, SC) at the rate of $11.5 \mathrm{lb} / 1000 \mathrm{ft}^{2}$. In Dec. 2017 and 2018, when all seedling selections had flowered annually for a minimum of 4 years, individual seedlings were rated for seed set using the scale of $1=$ no fruit, $2=1$ to 10 fruit per plant, $3=11$ to 50 fruit, and $4=>50$ fruit per plant.

Although carolina laurel cherry is often listed as having perfect flowers (Dirr, 1998), the species is known to be andromonoecious (Wolfe and Drapalik, 1999), producing both male and bisexual flowers. A study was conducted in Mar. 2018 to determine the number of male flowers and all-male racemes on two control plants and 15 advanced selections. Ten random branches were collected from each tree. Five random racemes on each branch were selected and the gender of 10 flowers per raceme was determined. The results of this study are based on the measurement of 170 branches, 850 racemes, and 8500 flowers. Data calculations for number of male flowers, fruit rating, and number of all-male racemes and correlation analysis were conducted using the Statistical Package add-on in

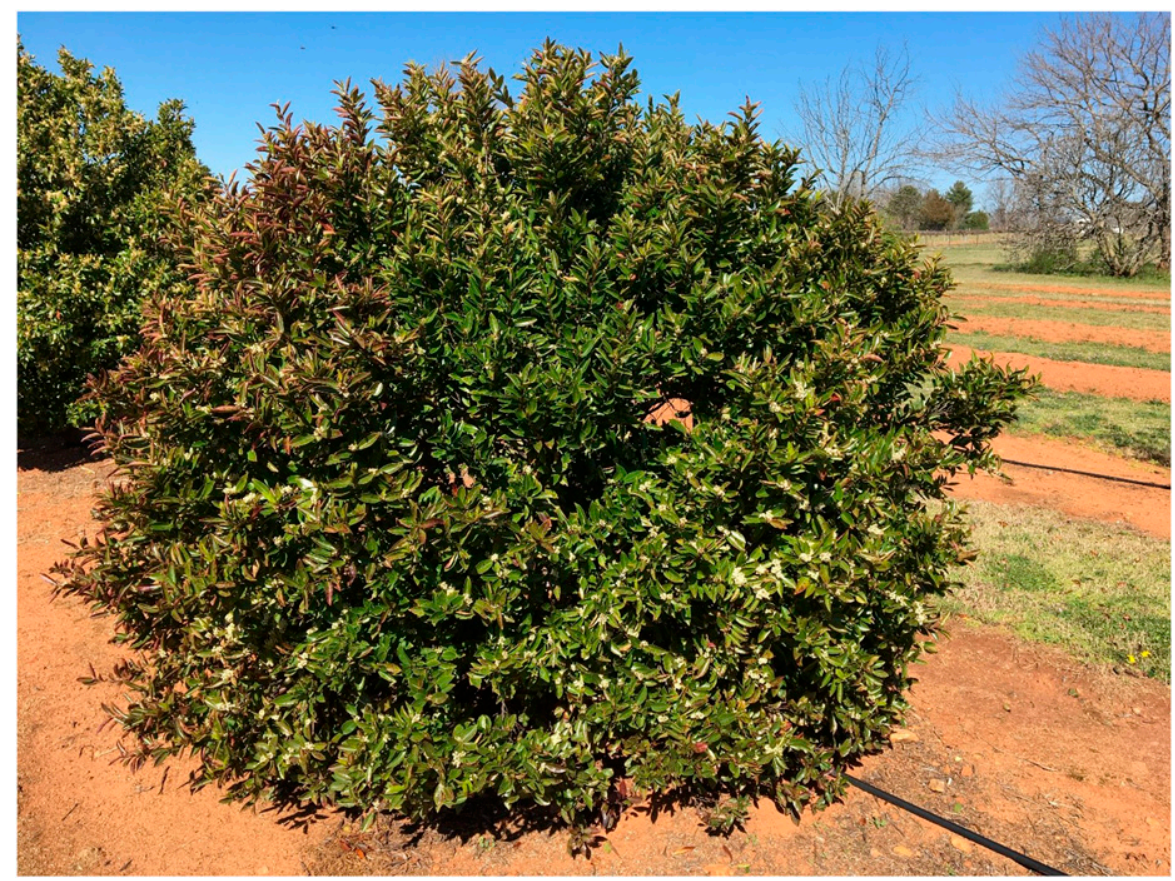

Fig. 1. A compact, globose, sterile M1 (first generation of mutagen-treated seedlings) carolina laurel cherry selection with remaining hints of reddish winter coloration. Photograph taken 2 Mar. 2017 as flower buds are expanding. 
Excel (Microsoft Office 2016; Microsoft, Redmond, WA).

\section{Results}

Germination of control seed in the irradiation study was $>95 \%$ (data not shown). Germination of seed treated at 50 Gy was $\approx 60 \%, 100$ Gy $\approx 20 \%$, and $150 \mathrm{~Gy} \approx 10 \%$. Thus, an $\mathrm{LD}_{50}$ would be between 50 Gy and 100 Gy. Of the three Ml seedlings that have remained sterile, two were treated at $150 \mathrm{~Gy}$, and one at $100 \mathrm{~Gy}$. One of the three Ml plants has a unique, globose growth habit and purplish/red winter coloration to the foliage (Fig. 1).

In $2017,73 \%$ of the treated M2 seedlings in the field produced no fruit, $23 \%$ produced minimal fruit, and $4 \%$ produced moderate levels of fruit (Table 1). For $2018,77 \%$ of the remaining plants produced no fruit and $8 \%$ had a heavy fruit set $(>50$ fruit/tree).

Of the 8500 individual flowers evaluated from 17 selections, $41 \%$ of the flowers were male (Fig. 2). The range of male flowers per plant sampled was from 22 to 415 with a mean $( \pm \mathrm{SE})$ of $205 \pm 28$ male flowers per 500 flowers sampled. The percentage of male flowers per plant ranged from $8 \%$ to $83 \%$. The number of racemes with all-male flowers per individual selection (50 racemes per selection) ranged from 1 to 32 with a mean of $10 \pm 2$ (data not shown). The fruit rating for the 17 selections ranged from 1 to 4 with a mean of $1.63 \pm 0.40$. Of the $15 \mathrm{M} 2$ selections, 13 produced no fruit, 1 produced minimal fruit, and 1 produced heavy fruit. There was no significant correlation between the fruit rating and the number of male flowers per plant or the number of all-male racemes per plant. However, there was a positive $(P<0.001)$ correlation of $r=0.89$ between the number of male flowers per plant and the number of all-male racemes per plant.

\section{Discussion}

As of Dec. 2018, we have 80 M2 selections that have not produced fruit. Based on 1509 original M2 seedlings, this gives a potential sterility rate of $5.3 \%$. Three of the original $62 \mathrm{Ml}$ seedlings are sterile, giving a rate of $4.8 \%$.

Our study is in agreement with that of Wolfe and Drapalik (1999) that carolina laurel cherry is an
Table 1. Percentage of carolina laurel cherry M2 seedlings [second-generation seedlings from MI (first generation of mutagen-treated seedlings) parents] from seed first treated in 2008 with Cobalt-60 that produced fruit in $2017(n=120)$ and $2018(\mathrm{n}=104)$. Seedlings were planted in the field in Watkinsville, GA, in 2014 or 2015. Data for fruit rating were taken in December of each year.

\begin{tabular}{lcc}
\hline Rating $(\mathbf{1 - 4} \text { scale })^{\mathrm{z}}$ & $\mathbf{2 0 1 7}(\%)$ & $\mathbf{2 0 1 8 ( \% )}$ \\
\hline 1 & 73 & 77 \\
2 & 23 & 6 \\
3 & 4 & 9 \\
4 & 0 & 8 \\
\hline${ }^{\mathrm{z}} 1=0$ (no fruit) $2=1-10$ (minimal fruit) $3=11-50$ (moderate fruit) $4=>50$ (heavy fruit) &
\end{tabular}

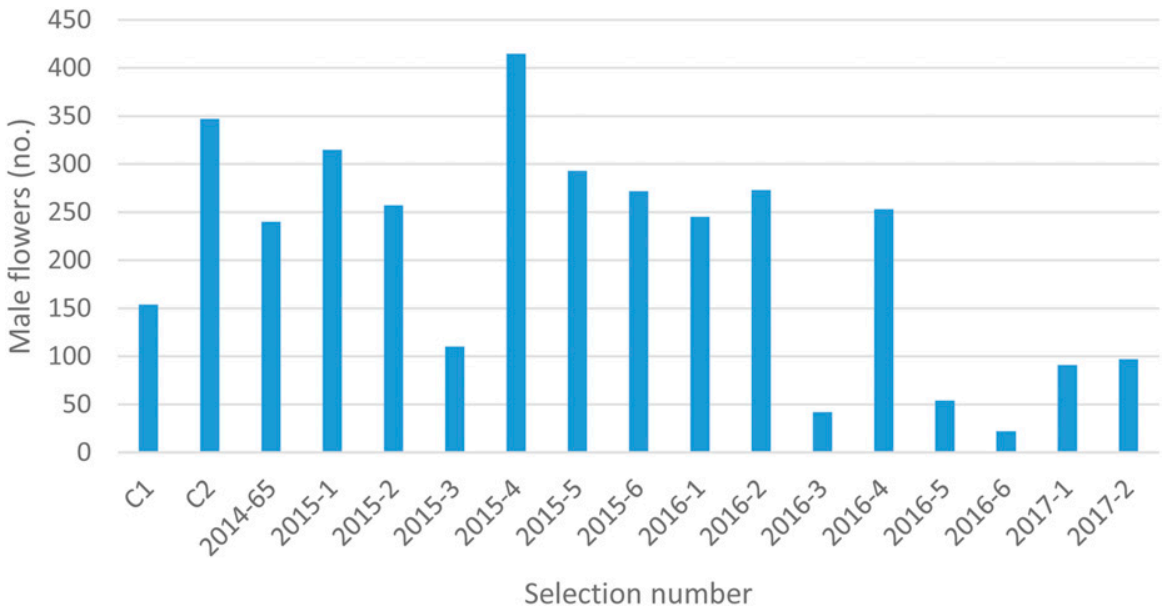

Fig. 2. Number of male flowers (range 22-415) for each of the 17 selections of carolina laurel cherry evaluated in 2018; 500 flowers per selection were evaluated as being male or bisexual. $\mathrm{Cl}$ and $\mathrm{C} 2$ refer to the two nontreated control plants; 2014-65 is an Ml selection (first generation of mutagen-treated seedlings), and the remaining selections are all M2 seedlings (second-generation seedlings from M1 parents).

andromonoecious species. In their study, $\approx 80 \%$ of the flowers sampled were male compared with $41 \%$ in this study. Furthermore, male flower production on a per-plant level in their study ranged from $38 \%$ to $98 \%$ with 5 of their 10 plants having $>80 \%$ male flowers. Male flower production in this study on a per-plant level ranged from $8 \%$ to $83 \%$ with only 3 of 17 plants producing more than $60 \%$ male flowers. Of interest is that the one M2 selection that had a heavy fruit rating $=4(>50$ per plant $)$ had the lowest number of male flowers in the study with only 22 . The two control plants that both had fruit ratings of 4 had $31 \%$ and $69 \%$ male flowers, respectively. Interestingly, the colored engraving plate of carolina laurel cherry [as wild orange (Cerasus caroliniana)] in The North American Sylva (Michaux, 1819) shows flowering racemes that appear

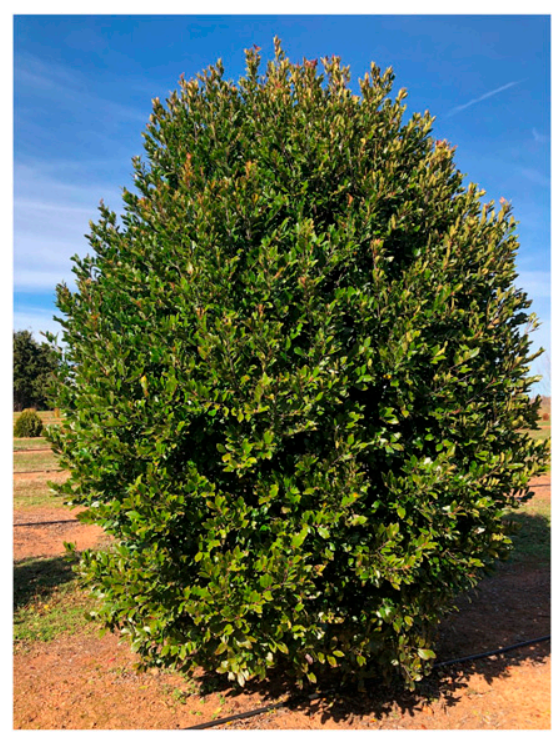

Fig. 3. An upright sterile M2 (secondgeneration seedling from Ml parents) carolina laurel cherry selection that has received no pruning. Photograph taken 26 Feb. 2018. 
to have all-male flowers, although fruit from the previous year is present. The results of this study indicate that irradiation of carolina laurel cherry plants can decrease the number of male flowers on some selections while also increasing the chances of creating sterile plants for the nursery and landscape trades. Further studies would be required to determine the causes behind reduced fruit set in irradiated seedlings. Elite sterile selections with good growth form (Fig. 3) will be propagated from cuttings for further container and field studies. It is projected that cultivar selections will be patented by the University of Georgia Research Foundation on release to the industry.

\section{Literature cited}

Dirr, M.A. 1998. Manual of woody landscape plants. Stipes Publ., Champaign, IL.
Duncan, W.H. 1950. Preliminary reports on the flora of Georgia. 2. Distribution of 87 trees. Amer. Midl. Nat. 43(3): 742-761.

Gilman, E.F. and D.G. Watson. 2006. Prunus caroliniana: Cherry-laurel. Univ. Florida, Inst. Food Agr. Sci. Ext. ENH664. 18 Dec. 2018. <https://edis.ifas. ufl.edu/pdffiles/ST/ST50500.pdf>.

Godfrey, R.K. 1988. Trees, shrubs, and woody vines of Northern Florida and adjacent Georgia and Alabama. Univ. Georgia Press, Athens, GA.

Harper, R.M. 1906. A phytogeographical sketch of the Altamaha grit region of the coastal plain of Georgia. Ann. N. Y. Acad. Sci. 17:1-415.

Michaux, F.A. 1819. The North American sylva. Vol. II. C. D'Hautel, Paris, France.

Radford, A.E., H.E. Ahles, and C.R. Bell. 1968. Manual of the vascular flora of the Carolinas. Univ. North Carolina Press, Chapel Hill, NC.
Ranney, T.G. 1994. Differential tolerance of eleven Prunus taxa to root zone flooding. J. Environ. Hort. 12(3):138141.

Shu, Q.Y., B.P. Forster, and H. Nakagawa. 2012. Plant mutation breeding and biotechnology. CABI, Cambridge, MA.

Skeate, S.T. 1987. Interactions between birds and fruits in a northern Florida hammock community. Ecology 68(2):297-309.

U.S. Department of Agriculture. 2018. Prunus caroliniana. 29 Jan. 2019. <https://plants.usda.gov/core/profile? symbol $=$ PRCA $>$.

Wolfe, L.M. and D.J. Drapalik. 1999. Variation in the degree of andromonoecy in Prunus caroliniana. Castanea 64(3):259262. 